\title{
Biodegradation of Polyhydroxyalkanoates in Natural Water Environments
}

\author{
Tatiana G. Volova ${ }^{\mathrm{a}, \mathrm{b} *}$, \\ Anatoly N. Boyandin ${ }^{a, b}$, Svetlana V. Prudnikova ${ }^{b}$, \\ Michail I. Gladyshev a and Iosif I. Gitelson ${ }^{a}$ \\ ${ }^{a}$ Institute of Biophysics SB RAS \\ 50/50 Akademgorodok, Krasnoyarsk, 660036, Russia \\ ${ }^{b}$ Siberian Federal University \\ 79 Svobodny, Krasnoyarsk, 660041, Russia
}

Received 04.02.2015, received in revised form 28.02.2015, accepted 16.04.2015

The review reports studies of PHA biodegradation behavior in natural freshwater and marine environments. The factors determining polymer degradation rates in water basin include the temperature and the mineral component of the water, the structure of the aquatic ecosystem and bacterioplankton composition. Anaerobic degradation occurs at slower rates as compared with aerobic process. One of the factors limiting PHA degradation rates is deficiency of dissolved mineral phosphorus, which hinders the development of microbial components of the ecosystem. Differences in biodegradation patterns of PHA specimens are accounted for by different structures and surface areas of specimens, which influence the adhesion of microorganisms. Bacteria are main PHA destructors in water ecosystems as opposed to soil environments where micromycetes are most significant degraders.

Keywords: polyhydroxyalkanoates (PHAs), PHA properties, PHA biodegradation, PHA degrading microorganisms, water environments.

DOI: 10.17516/1997-1389-2015-8-2-168-186.

(c) Siberian Federal University. All rights reserved

* Corresponding author E-mail address: volova45@mail.ru 


\title{
Биодеградация полигидроксиалканоатов
}

\section{в природных водных экосистемах}

\author{
Т.Г. Волова ${ }^{\mathrm{a}, \tilde{\sigma} *}$, А.Н. Бояндин ${ }^{\mathrm{a}, \tilde{\sigma}}$, \\ С.В. Прудникова ${ }^{\sigma}$ М.И. Гладышев ${ }^{\mathrm{a}}$, И.И. Гительзон ${ }^{\mathrm{a}}$ \\ ${ }^{a}$ Институт биофизики СО РАН \\ Россия, 660036, Красноярск, Академгородок, 50/50 \\ ${ }^{6}$ Сибирский федеральный университет \\ Россия, 660041, Красноярск, пр. Свободный, 79
}

В обзоре приведены результаты исследований по биодеградации полигидроксиалканоатов (ПГА) в природных пресноводных и морских экосистемах. Факторы, определяющие скорости деградации полимеров в условиях водоема, включают температуру и минеральный состав воды, структуру водной экосистемы и состав бактериопланктона. При наличии в водоеме аэробной и анаэробной зон анаэробная деградаџия протекает с меньшими скоростями по сравнению с аэробной. Одним из факторов, ограничивающих скорости деградаџии ПГА, является недостаток растворенного минерального фосфора, препятствующий развитию микробных сообществ экосистемы. Отличия в особенностях биодеградации ПГА обусловлень также различными структурой и поверхностью образияов, влияющчими на адгезию микроорганизмов. Бактерии являются основными деструкторами ПГА в водных экосистемах, в отличие от почвенных, где наибольшее значение имеют микромицеть.

Ключевые слова: полигидроксиалканоатьл (ПГА), свойства ПГА, биодеградациия ПГА, микроорганизмы-деструкторы ПГА, водные экосистемы.

\section{Introduction}

Polyhydroxyalkanoates (PHAs), representing the developing industry of degradable bioplastics, are good candidates to gradually replace synthetic polymers. As the outputs of PHAs increase, studies examining degradation of these polymers in natural environments acquire increasing significance.

PHAs are degraded in biological media to form products innocuous to the environment: carbon dioxide and water under aerobic conditions or methane and water under anaerobic conditions. PHA biodegradation is performed by microorganisms that secrete intra- or extracellular PHA depolymerases, which differ in their molecular organization and substrate specificity (Jendrossek, Handrick, 2002). Six hundred PHA-depolymerases from various microorganisms have been identified by now; comparison of their amino-acid sequences provided a basis for uniting them in 8 superfamilies including 38 families (Knoll et al., 2009). Most PHA-degrading microorganisms contain only one depolymerase, but there are species that have several depolymerases. For example, Pseudomonas lemoignei, one of the best-studied PHA degraders, has at least six extracellular PHA depolymerases, encoded by phaZ1 - phaZ6 genes (Schöber et al., 2000). Three of them are specific for $\mathrm{P}(3 \mathrm{HB})$ and $\mathrm{P}(3 \mathrm{HB}-\mathrm{co}-3 \mathrm{HV})$ with low $3 \mathrm{HV}$ fractions $(\mathrm{P}(3 \mathrm{HB})$ depolymerases $\mathrm{A}, \mathrm{B}$, and $\mathrm{D}$ encoded 
by the phaZ1, phaZ2, and phaZ3 genes) (Jendrossek, Handrick, 2002).

The activity of these enzymes with the homopolyester $\mathrm{P}(3 \mathrm{HV})$ is below $5 \%$ of the activity obtained with $\mathrm{P}(3 \mathrm{HB})$ as a substrate. None of the three $\mathrm{P}(3 \mathrm{HB})$ depolymerases is able to produce clearing zones on opaque $\mathrm{P}(3 \mathrm{HV})$-granulecontaining agar. The two remaining PHA depolymerases $(\mathrm{P}(3 \mathrm{HB})$ depolymerase $\mathrm{C}$ and $\mathrm{P}(3 \mathrm{HV})$ depolymerase, encoded by phaZ5 and phaZ4, respectively) also degrade $\mathrm{P}(3 \mathrm{HB})$, but are additionally able to hydrolyze $\mathrm{P}(3 \mathrm{HV})$, with higher activity compared with depolymerases $\mathrm{A}, \mathrm{B}$, and $\mathrm{D}$. The sixth, $\mathrm{P}(3 \mathrm{HV})$ depolymerase, encoded by phaZ6, is an active degrader of $3 \mathrm{HV}$ or carbon sources with an odd number of carbon atoms.

PHAs are degraded intracellularly by intracellular depolymerases. It is assumed that intracellular depolymerases do not hydrolyze partially crystalline PHAs isolated from the biomass and that extracellular depolymerases are not substrate-specific towards the polymer present in cells as granules.

PHA chains can be degraded by cleaving. The attack starts at chain-folding surfaces and then degradation goes on perpendicularly to the lamella, until it reaches the solid lamellar center and stops. Some researchers assume that single crystals are preferentially attacked at the crystal ends rather than at chain-folding surfaces (Urmeneta et al., 1995; Hocking et al., 1996). Another degradation mechanism was proposed more recently (Nobes et al., 1998): the predominant effect observed with all crystals was a significant narrowing of the lamellae, suggesting an edge attack mechanism. Biodegradation of polyhydroxyalkanoates is performed by microorganisms, which inhabit different natural environments. Therefore, ecological and taxonomic studies need to be conducted to investigate the diversity of microorganisms degrading polymers in different biological media.

Microorganisms degrading poly(3-hydroxybutyrate) were first isolated more than 40 years ago (Chowdhury, 1963). The microorganisms identified belonged to several taxa: Bacillus, Pseudomonas, Streptomyces. Two years later, 16 other microorganisms degrading $\mathrm{P}(3 \mathrm{HB})$ extracellularly were described (Delafield et al., 1965). Then, as the range of the investigated PHAs broadened, microorganisms degrading not only homogenous hydroxybutyrate but also short- and medium-chain-length heteropolymers were isolated and described (Brandl, Puchner, 1992; Briese et al., 1994; Mergaert et al., 1993; 1994; 1995).

PHAs can be degraded by fungi. PHA degrading fungi have been isolated from freshwater, seawater, and sludge (Mergaert et al., 1996). Lee et al. (2005) isolated $\mathrm{P}(3 \mathrm{HB})$ degrading micromycetes from 15 natural habitats. Most of these were deuteromycetes (fungi imperfecti). Ninety-five fungal species have been investigated, among them 16 Ascomycetes species, 46 Basidiomycetes species, 26 Deuteromycetes species, 1 Mastigiomycetes species, 2 Myxomycetes species, and 2 Zygomycetes (Jendrossek, Handrick, 2002). Most PHA degraders are mesophilic microorganisms, but a few thermophilic species are able to degrade PHAs at elevated temperatures. Isolation of thermophilic microorganisms capable of PHA degradation is important for developing the technology of high-temperature composting - one of the main ways to dispose of biodegradable polymers. Oda et al. (1995) and Takeda (1998) studied P(3HB) degradation at elevated temperatures by Leptothrix sp. and Paecilomyces lilacinus.

Rather little consideration has been given to PHA biodegradation by anaerobic microorganisms, although anaerobic waste treatment is considered to be an efficient process, yield- 
ing biogas as a byproduct. Janssen and Schink (1993) isolated and identified an anaerobic bacterium, Ilyobacter delafildii, which can utilize poly(3-hydroxybutyrate). Anaerobic degradation of $\mathrm{P}(3 \mathrm{HB})$ and $\mathrm{P}(3 \mathrm{HB}-\mathrm{co}-3 \mathrm{HV})$ by Clostridium strains was reported by Abou-Zeid et al. (2001; 2004). Under anaerobic conditions, $\mathrm{P}(3 \mathrm{HB})$ was degraded more quickly than $\mathrm{P}(3 \mathrm{HB}-\mathrm{co}-3 \mathrm{HV})$. Elsewhere Morse et al. (2011) indicate that under anaerobic conditions samples with higher HHx fraction tended to have faster weight loss; on Day 7 of the degradation experiment, P3HB-co$10 \mathrm{~mol} \%-3 \mathrm{HHx}$ lost $80 \%$ of its original weight, while P3HB-co-3.8 mol \%-3HHx lost only $28 \%$.

To get insight into the degradation mechanism of PHAs, studies have been performed in various model systems (buffer solutions, enzyme solutions, blood, serum, cell cultures, microcosms) at different values of $\mathrm{pH}$, temperature, salinity of the medium, and other varied parameters. Polymers used in these investigations have various chemical compositions and different initial molecular weights and crystallinities; polymer items differ in shape and structure.

The usual parameters indicating degradation of PHAs and PHA items are a reduction in molecular weight and degree of crystallinity of a polymer as well as a change in the total mass of polymer items and their strength. In one of their earlier studies of PHA hydrolytic degradation, Doi et al. (1990) studied P(3HB), P(3HB-co-3HV), and $\mathrm{P}(3 \mathrm{HB}-\mathrm{co}-4 \mathrm{HB})$ films exposed in phosphate buffer ( $\mathrm{pH}$ 7.4) at different temperatures. During 180 days, none of the polymers exhibited any mass loss, but their molecular weight decreased, particularly that of $\mathrm{P}(3 \mathrm{HB}-\mathrm{co}-4 \mathrm{HB})$ (at $70^{\circ} \mathrm{C}$ its molecular weight almost halved). Martin et al. (2004) confirmed that poly(3-hydroxybutyrate) is not degradable in non-biological environments. During 10 weeks at $\mathrm{pH} 7.4$, the molecular weight of the polymer changed insignificantly and the total film mass remained unchanged. However, in con- trast to the data reported by Miller and Williams (1987), less crystalline P(3HB-co-3HV) copolymers were found to have a higher degradation rate in model systems than highly crystalline $\mathrm{P}(3 \mathrm{HB})$. It was determined that kinetics of PHA degradation was also influenced by the initial $\mathrm{Mw}$ of the material (Yasin and Tighe, 1992 a, b). Hydrolytic degradation of PHA is a long process, which can last for months, due to the high crystallinity of the PHA or the hydrophobic nature of long alkyl chains. Blending of $\mathrm{P}(3 \mathrm{HB})$ with other polymers or plasticizing agents increases its degradation rate. Films of $\mathrm{P}(3 \mathrm{HB})$ and $\mathrm{P}(3 \mathrm{HB})$-tetramethyl cellulose (TMC) exposed in a phosphate buffer (at $\mathrm{pH} 7.0$ and $37^{\circ} \mathrm{C}$ ) behaved differently: the mass of $\mathrm{P}(3 \mathrm{HB})$ films remained almost unchanged, but the composite films were degraded (Lootz et al., 1998). Amorphous or hydrophilic additives promote water penetration into the polymer and increase biodegradation rate. Blends of $\mathrm{P}(3 \mathrm{HB}-$ co-3HV) with polylactide (PLA) and hydrophilic $\mathrm{PEG}$ were incubated in tetraborate buffer $(\mathrm{pH}=10)$ at $37^{\circ} \mathrm{C}$ for 160 days and their degradation rate was higher than that of pure $\mathrm{P}(3 \mathrm{HB}-\mathrm{co}-3 \mathrm{HV})$ (Renard et al., 2004).

Shangguan et al. (2006) treated P(3HBco-3HHx) with UV radiation and recorded an increase in the polymer degradation rate. After 15 weeks of degradation in simulated body fluid, films prepared from 8 and $16 \mathrm{~h}$ UV-treated $\mathrm{P}(3 \mathrm{HB}-\mathrm{co}-3 \mathrm{HHx})$ powders maintained $92 \%$ and $87 \%$ of their original weights, respectively, while the untreated $\mathrm{P}(3 \mathrm{HB}-\mathrm{co}-3 \mathrm{HHx})$ films lost only $1 \%$ of its weight. The $\mathrm{P}(3 \mathrm{HB})$ degradation rate was accelerated about threefold in vitro by addition of pancreatin to the buffer solution (Freier et al., 2002). Yamane et al. (2001) reported an investigation of the degradation dynamics of $\mathrm{P}(3 \mathrm{HB})$ monofilament fibers, using a $\mathrm{P}(3 \mathrm{HB})$ depolymerase. The fibers were placed in potassium phosphate buffer ( $\mathrm{pH}$ 7.4) and 136 units of PHA depolymerase from Commamonas 
testosterone. In this model system the fibers were rapidly (within 10-26 h) degraded. Their surface was covered with deep cracks and fractures and their mechanical properties changed. After $25 \mathrm{~h}$ of degradation, a $60 \%$ decrease in tensile modulus and an $80 \%$ decrease in tensile strength were registered.

Enzymatic PHA degradation occurs at rates that are two or three orders of magnitude faster than those of hydrolytic degradation (Kumagai et al., 1992; Kusaka et al., 1999). PHA-hydrolyzing enzymes are substrate specific for different PHAs. In addition to that, physical properties of the polymer also influence its biodegradability. The most important factors influencing PHA biodegradability are the stereoconfiguration, crystallinity, molecular weight, and chemical composition of the polymer. Stereoconfiguration is considered to be a very significant factor for PHA degradation (Abe et al., 1996; Doi et al., 1992). All PHA-depolymerases are specific for polymers consisting of monomers in the (R) configuration. Chemically synthesized PHAs in the $(\mathrm{S})$ configuration are not degraded by $\mathrm{P}(3 \mathrm{HB})$ depolymerases. PHAs with higher degrees of crystallinity are less degradable (Kumagai et al., 1992; Nishida and Tokiwa, 1993; Tomasi et al., 1996; Koyama and Doi, 1997; Abe and Doi, 1999; Wen, Lu, 2012). Studies of PHA films showed that extracellular PHA depolymerase hydrolyzed preferentially chains in the amorphous state and subsequently eroded chains in the crystalline state (Doi et al., 1989; 1992 b; Hocking et al., 1996).

Thus, analysis of the available literature shows that there is no unanimity of opinion regarding biodegradation behavior of a given polymer in a given biological environment. The question how the composition and properties of the PHA and environmental conditions (temperature, $\mathrm{pH}$, salinity, and composition of the microbial community) influence the PHA biodegradation rate still remains unanswered.

\section{PHA degradation in freshwater ecosystems}

There have been rather few reports regarding PHA degradation behavior under natural conditions, in water environments, in particular.

In one of such experiments, PHA degradation was investigated in two freshwater lakes: Lesnoye and Bugach (Volova et al., 2006; 2007). $\mathrm{P}(3 \mathrm{HB}-\mathrm{co}-3 \mathrm{HV})$ film discs were placed into nylon mesh containers and submerged in the lakes at a depth of $1 \mathrm{~m}$. In Bugach, several PHA specimens were buried in the anaerobic layer of bottom black mud (at a depth of $4 \mathrm{~m}$ from the lake surface). Two experiments were performed: from May 17 to June 21, 2006 and from August 9 to September 27, 2006.

During the first experiment, the water temperature range in lake Bugach was $5-20^{\circ} \mathrm{C}$ and in lake Lesnoye $-8-25^{\circ} \mathrm{C}$. $\mathrm{P}(3 \mathrm{HB}-\mathrm{co}-3 \mathrm{HV}) \mathrm{deg}$ radation occurred at higher rates in lake Bugach, with the specific degradation rate $1.2 \times 10^{-2} \mathrm{~d}^{-1}$. The half-life of the copolymer in the littoral aerobic layer at a depth of $1 \mathrm{~m}$ was $41 \mathrm{~d}$. In lake Lesnoye, polymer degradation was much slower (with the specific degradation rate $0.5 \times 10^{-2} \mathrm{~d}^{-1}$ ); the half-life of the copolymer was $109 \mathrm{~d}$.

The second experiment was started when the water temperature was higher $\left(19^{\circ} \mathrm{C}\right)$, and degradation of the copolymer in lake Bugach occurred at higher rates than during the first experiment, while polymer degradation rates in lake Lesnoye decreased. In the aerobic zone of lake Bugach, at a depth of $1 \mathrm{~m}$, the half-life of the specimens was $21 \mathrm{~d}$, i.e. the specimens were degraded nearly twice faster than during the first experiment. At the end of the 49-day experiment, polymer films submerged in lake Bugach were almost completely degraded, and their residual mass comprised 2.3-5.2 \% of their initial mass. During that period of time, blue-green algae bloom occurred in the water of lake Bugach; the dominant algal species were Anabaena flos-aquae (Lyngb.) Breb and 
Synechocystis salina Wisl, a small unicellular cyanobacterium. The development of these blue-greens in the ecosystem of lake Bugach must be indicative of their contribution to PHA biodegradation.

In lake Lesnoye, no development of bluegreens was observed, and the abundance of bacterioplankton decreased compared with the first experiment. In Lesnoye, the mass loss of PHA films was $14 \%$. Although the water temperature was higher than during the first experiment, the half-life of the polymer increased to $194 \mathrm{~d}$, and it was more than 1.5 longer than in the first experiment.

Comparison of PHA degradation rates in the near-bottom anaerobic layer (black mud) and in the 1-m-deep littoral aerobic layer of lake Bugach showed that polymer degradation was slower in the anaerobic layer. During the first experiment, the half-life of the polymer was $55 \mathrm{~d}$, and after 35 days, the mass loss was $21 \%$. During the second experiment, when the water temperature was higher, polymer degradation rate became higher, and the half-life of the specimens dropped to 32 d (Fig. 1).

Comparison of degradation behavior of $\mathrm{P}(3 \mathrm{HB}-\mathrm{co}-3 \mathrm{HV})$ in two lakes showed that the factors determining polymer degradation rates include not only the temperature of the environment but also the structure of the aquatic ecosystem and the mineral component of the water, which is responsible for the development of bacterioplankton - the major PHA degrader. $\mathrm{P}(3 \mathrm{HB}-\mathrm{co}-3 \mathrm{HV})$ degradation rates under aerobic and anaerobic conditions were compared for the first time, showing that anaerobic degradation occurs at slower rates. Deficiency of dissolved mineral phosphorus, which hinders the development of ecosystem components, was proposed as a factor limiting $\mathrm{P}(3 \mathrm{HB}-\mathrm{co}-3 \mathrm{HV})$ degradation rates.

Mass loss dynamics of two types of polymers ( $\mathrm{P}(3 \mathrm{HB})$ and $\mathrm{P}(3 \mathrm{HV}-\mathrm{co} 3 \mathrm{HV}))$ was studied in tropical freshwater environments in Vietnam. Films and pellets were incubated in an artificial pool and in the Cai River. The degradation rate of polymer specimens in the river water was influenced more by their shape than by their chemical composition. Both homopolymer and copolymer films were completely degraded after 2 month incubation, while the overall mass loss of polymer pellets in the river water was 65-66 \% (Fig. 2). In the water of the artificial pool, the mass loss of the polymer specimens was greater than in
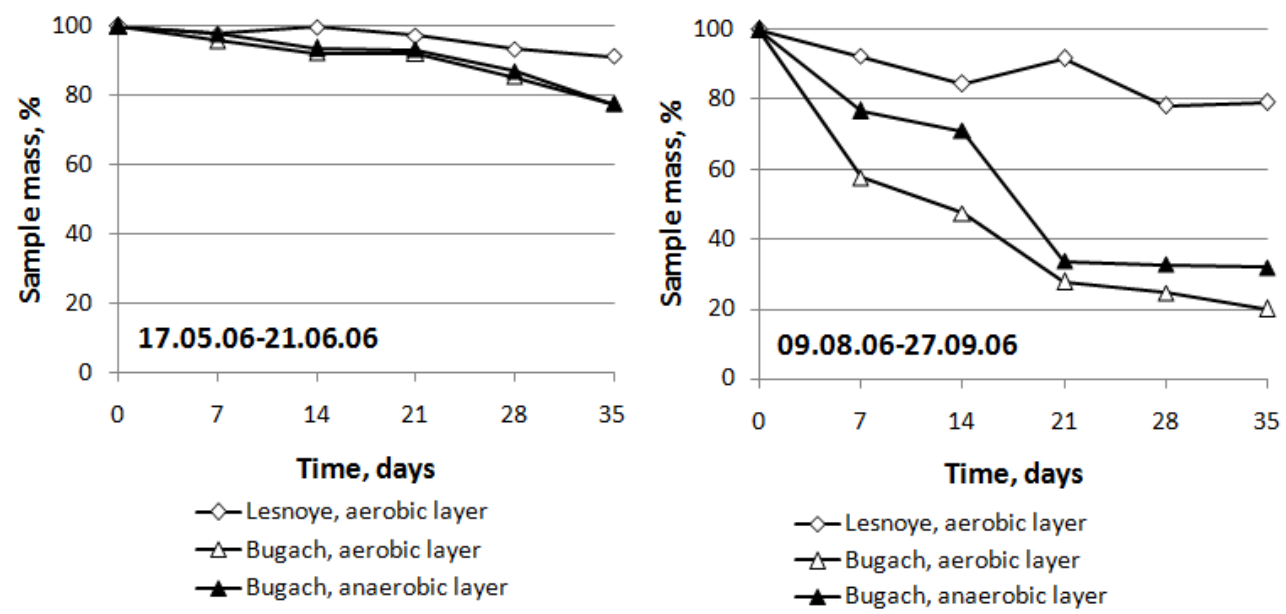

Fig. 1. Dynamics of the mass of PHBV specimens in freshwater lakes Lesnoye and Bugach 

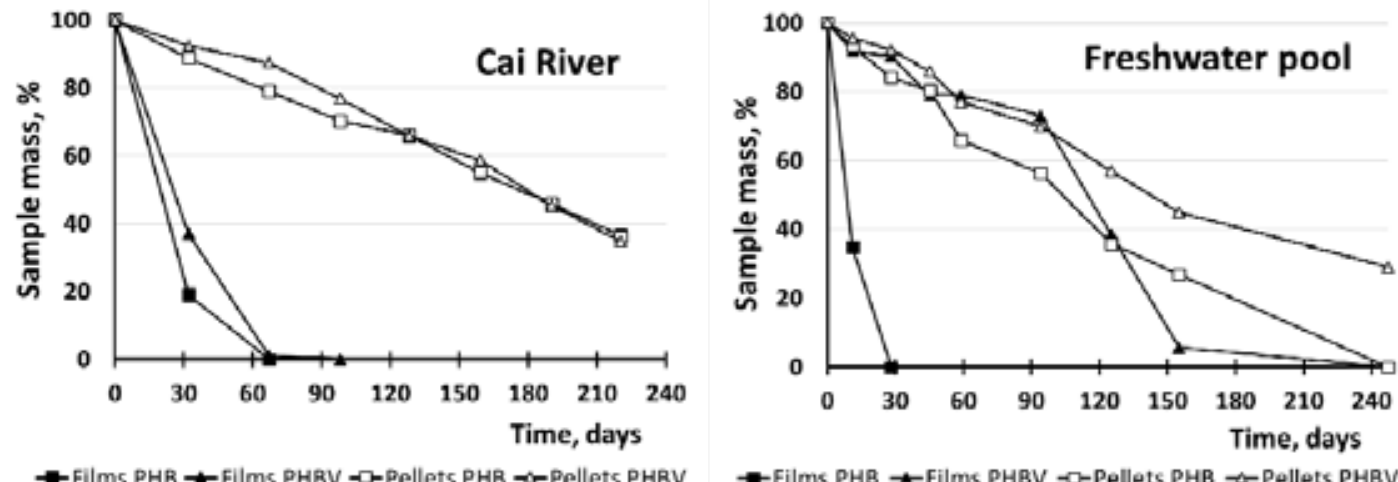

Fig. 2. Dynamics of the mass of polymer specimens in tropical fresh water (Prudnikova et al., 2015)

Table 1. The occurrence of microorganisms in samples of tropical water ecosystems

\begin{tabular}{|c|c|c|c|}
\hline \multirow{2}{*}{\multicolumn{2}{|c|}{ Soil samples }} & \multicolumn{2}{|c|}{ PHA degrading microorganisms } \\
\hline & & \multirow{2}{*}{$\begin{array}{l}\text { Bacteria } \\
\text { Acinetobacter sp. } \\
\text { Bacillus sp. }\end{array}$} & \multirow[b]{2}{*}{ Not found } \\
\hline & The Cai river & & \\
\hline Freshwater & Freshwater pool & $\begin{array}{l}\text { Bacillus } \mathrm{sp} . \\
\text { Pseudomanas } \mathrm{sp} . \\
\text { Corynebacterium } \mathrm{sp} . \\
\text { Mycobacterium } \mathrm{sp} . \\
\text { Streptomyces } \mathrm{sp} .\end{array}$ & Aspergillus candidus \\
\hline Seawater & $\begin{array}{c}\text { The South China } \\
\text { Sea }\end{array}$ & $\begin{array}{l}\text { Bacillus } \text { sp. } \\
\text { Gracilibacillus } \text { sp. } \\
\text { Enterobacter cloacae }\end{array}$ & $\begin{array}{l}\text { Malbranchea sp. } \\
\text { Verticillium alba }\end{array}$ \\
\hline
\end{tabular}

the flowing water, and it was influenced by the chemical composition of the polymers. $\mathrm{P}(3 \mathrm{HB})$ films were completely degraded after 1 month incubation, while $\mathrm{P}(3 \mathrm{HB}-\mathrm{co}-3 \mathrm{HV})$ films remained undegraded for 6 months. The mass loss of the pellets reached 62 to $90 \%$ for the copolymer and homopolymer, respectively, after 7 month incubation.

Hydrochemical properties of both water environments were similar and stable: water temperature $26-28^{\circ} \mathrm{C}$, salinity $1.4-1.7 \%$, $\mathrm{pH}$ 7.1-7.2, oxygen concentration 1.1-3.4 mg/ml. An important role in biodegradation of polymer specimens must have been played by the microflora of the water environments and the specificity of PHA degrading strains. Microbiological analy- sis showed that the total counts of organotrophic bacteria in biofilms on polymer specimens incubated in the Cai River were 3-4 times higher than their counts in biofilms on the specimens in the artificial pool. The percent of PHA degrading bacteria in the total organotrophic microorganisms was also higher in the Cai River, reaching 7 to $17 \%$ on different specimens. The taxonomic composition of bacteria with PHA depolymerases was, however, more diverse in the pool water (Table 1), where representatives of Bacillus, Pseudomonas, Corynebacterium, Mycobacterium, and actinobacteria were detected (Fig. 3). In the Cai River, PHA degrading bacteria were represented by Bacillus and Acinetobacter species (Fig. 4). 

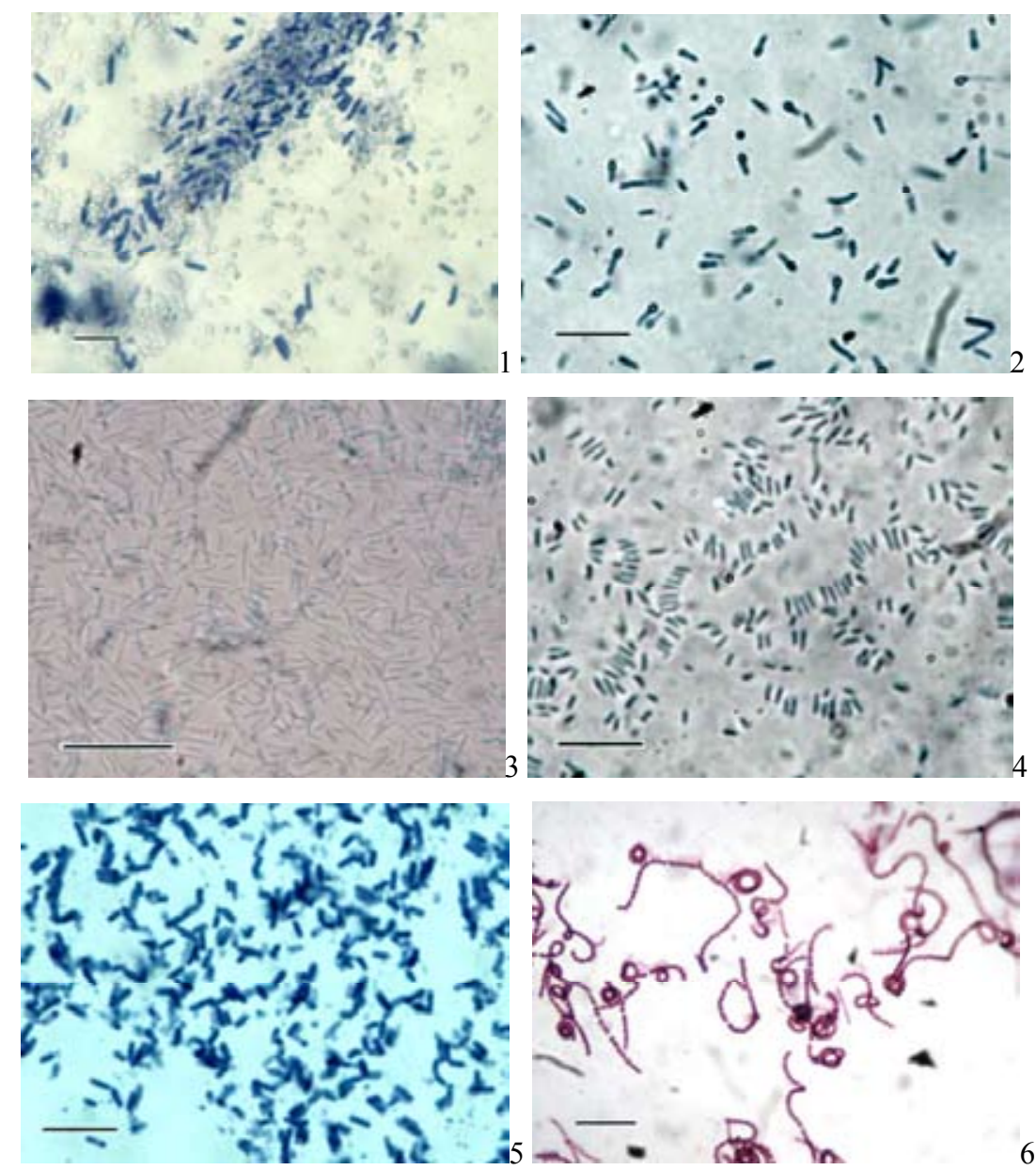

Fig. 3. PHA-degrading bacteria isolated from freshwater pool: 1, 2 - Bacillus, 3 - Pseudomonas, 4 Corynebacterium, 5 - Mycobacterium, 6 - Streptomyces. Scale $10 \mu \mathrm{m}$ (Prudnikova et al., 2015)
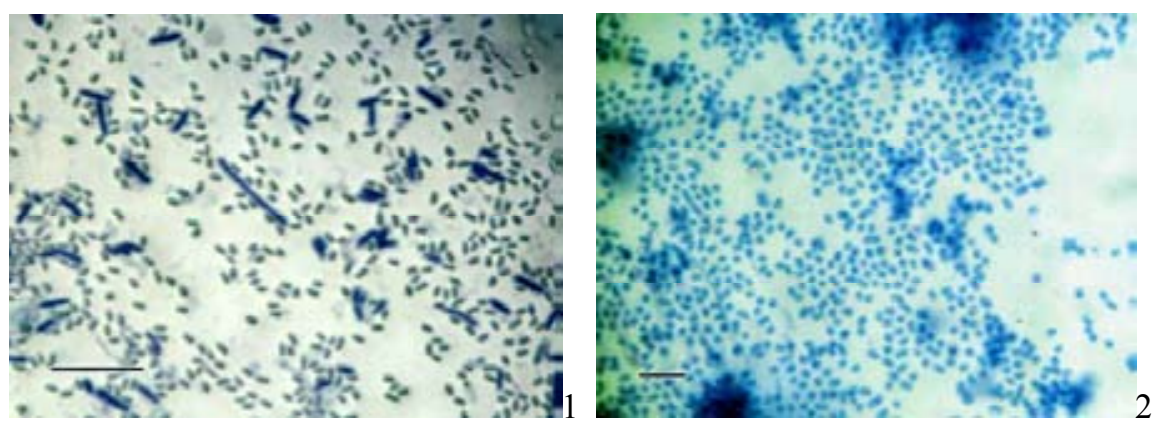

Fig. 4. PHA-degrading bacteria isolated from the Cai river: 1 - Bacillus, 2 - Acinetobacter. Scale $10 \mu \mathrm{m}$ (Prudnikova et al., 2015) 


\section{PHA degradation}

\section{in saltwater ecosystems}

Experiments in saltwater environments were more numerous. Authors of one of the first papers in this field monitored degradation of $\mathrm{P}(3 \mathrm{HB}-\mathrm{co}-3 \mathrm{HV})$ and $\mathrm{P}(3 \mathrm{HB}-\mathrm{co}-4 \mathrm{HB})$ specimens in the Sea of Japan for one year (Doi et al., 1992). They recorded a decrease in polymer molecular weight and erosion of the surface of the specimens, which were related to the season and water temperature. Imam et al. (1999) studied degradation of $\mathrm{P}(3 \mathrm{HB}-\mathrm{co}-3 \mathrm{HV})$ compared to cornstarch and blends of cornstarch and $\mathrm{P}(3 \mathrm{HB}-\mathrm{co}-3 \mathrm{HV})$ in tropical coastal waters of Puerto Rico. The specimens were placed at the edge of a mangrove stand, within a mangrove stand, among the coastal reefs, and in open water, at a depth of 1 meter. Specimens exposed to seawater were degraded slower than those at the other stations. Degradation of $100 \%$ P(3HB-co$3 \mathrm{HV})$ started after a pronounced lag period, at day 50 of the exposure; the degradation rate was very low, the rates of weight loss were not higher than $0.1 \%$ day $^{-1}$; the polymer had a half-life of 158 days. Microbial counts were much lower in the sea than in the mangrove stand, leading to different polymer degradation rates. Microbial biofilm on the surface of the specimens placed in the sea was less developed than on the specimens placed in other stations, and it was only formed after a certain lag period.

Rutkowska and co-authors (2008) monitored degradation of $\mathrm{P}(3 \mathrm{HB}-\mathrm{co}-3 \mathrm{HV})$ films in Gdynia Harbor of the Baltic Sea for 6 weeks and recorded $60 \%$ degradation. Blending of biological polymer and atactic poly((R,S)-3-hydroxybutyrate) was found to slow down degradation rates. Professor Mergaert and colleagues (Mergaert et al., 1995) monitored PHA degradation in small freshwater ponds and in seawater, in the Zeebrugge Harbor (Belgium). The recorded degradation rate of $\mathrm{P}(3 \mathrm{HB}-\mathrm{co}-3 \mathrm{HV})$ in the sea was higher than in freshwater ponds. In freshwater ponds, the mass of $\mathrm{P}(3 \mathrm{HB})$ specimens had decreased to $31 \%$ of their pre-exposure mass and the mass of the copolymer to $77 \%$ over one year, while in seawater the mass of $\mathrm{P}(3 \mathrm{HB})$ specimens had decreased to $31 \%$ of their pre-exposure mass over 270 days and the mass of the copolymer - to $49-52 \%$. Although the mass loss was considerable, no changes in the molecular weight of the PHA itself were recorded.

Sridewi and co-authors (2006) studied degradation of $\mathrm{P}(3 \mathrm{HB}), \mathrm{P}(3 \mathrm{HB}-\mathrm{co}-3 \mathrm{HV})(5 \mathrm{~mol}$. \% of 3-hydroxyvalerate) and $\mathrm{P}(3 \mathrm{HB}-\mathrm{co}-3 \mathrm{HHx})$ (5 mol. \% of hydroxyhexanoate) films in tropical mangrove ecosystems of Sungai Pinang, Malaysia, in different zones (in the surface water layer, deep in the sediment, in open water, and in mangrove stand). Copolymer specimens, which were less crystalline and whose surface was more porous, degraded faster than $\mathrm{P}(3 \mathrm{HB})$; the highest degradation rate was recorded for $\mathrm{P}(3 \mathrm{HB}-\mathrm{co}-3 \mathrm{HHx})$ films. The authors ascribed the differences in degradation rates to different structural and physicochemical properties of the surfaces of the films prepared from various PHAs, causing stronger or weaker attachment of microorganisms onto the surface, and to the specificity of PHA extracellular depolymerases produced by these microorganisms.

Environmental degradation of PHAs and oil palm-based composites was investigated in natural ecosystem of Harapan Lake and Science Garden of Universiti Sains Malaysia (Salim et al., 2012). Been found to the rate of degradation in the lake was higher compared to that in the soil.

There are a few marine microorganisms that have been identified as PHA degraders: the bacteria Pseudoalteromonas sp. NRRL B-30083 (Takaku et al., 2006), Marinobacter sp. NK-1 (Kim, Rhee, 2003), Alcaligenes faecalis AE122 (Kasuya et al., 1997) and the actinomycetes Nocardiopsis aegyptia (Suyama et al., 1998) and Streptomyces 
sp. SNG9 (Takaku et al., 2006). Their ability to secrete extracellular depolymerases and utilize both $\mathrm{P}(3 \mathrm{HB})$ and $\mathrm{P}(3 \mathrm{HB}-\mathrm{co}-3 \mathrm{HV})$ has been proven experimentally. These data, obtained in various marine ecosystems of different parts of the world, cannot provide a universal PHA biodegradation pattern in saltwater environments.

Volova et al. (2010) studied PHA degradation behavior in marine water in the tropics. As the PHA biodegradation rate is known to be influenced not only by different factors in a given environment such as weather conditions and microbial population but also by the chemical composition of the PHA, the technique used to process it, and geometry of the polymer, in this study we compared the rates of biodegradation of PHAs in the form of discs cut out of the films prepared by the solvent casting technique and compacted pellets prepared by cold compaction of finely powdered polymer. Specimens were prepared from the polymer of 3-hydroxybutyric acid $(\mathrm{P}(3 \mathrm{HB}))$ and a copolymer of 3-hydroxybutyric and 3-hydroxyvaleric acids (P(3HB-co-3HV)) containing $11 \mathrm{~mol} . \%$ of hydroxyvalerate.

PHA degradability was examined in the tropics, at the Marine Research and Testing Station of the Vietnam-Russia Tropical Center, in the South China Sea (Vietnam).

Hydrochemical parameters of seawater remained practically unchanged throughout the experiment. The average temperature of the water was $28.75 \pm 1.65^{\circ} \mathrm{C}$, with the minimum $27.1^{\circ} \mathrm{C}$ and the maximum $30.4^{\circ} \mathrm{C}$. Water $\mathrm{pH}$ values were close to neutral, varying insignificantly, between 7.0 and 7.5. The salinity of the water varied within the range $32-35 \%$; the average salinity in the study period was $34 \%$. Dissolved oxygen concentration varied from 5.4 to $8.3 \mathrm{mg} / \mathrm{ml}$.

Specimens of different shapes prepared by different techniques biodegraded at different rates. More rapid degradation was recorded in films, which had a large surface area and had been prepared by the technique that affected the polymer in the least degree. In 160 days after the specimens had been submerged in seawater, the residual mass of $\mathrm{P}(3 \mathrm{HB})$ and $\mathrm{P}(3 \mathrm{HB}-\mathrm{co}-$ $3 \mathrm{HV}$ ) films was $58 \%$ and $54 \%$, respectively, i.e. the mass loss of the specimens was almost equal. Over the first 120 days of exposure, the mass loss of the specimens occurred gradually, i.e. their degradation rates remained the same. A more significant weight loss was recorded for the following 20 days, suggesting more rapid degradation. The degradation behavior of compacted PHA pellets was somewhat different. Over the first 80 days, the mass of the specimens remained almost unchanged; degradation occurred between days 80 and 160 . The residual mass of $\mathrm{P}(3 \mathrm{HB})$ and $\mathrm{P}(3 \mathrm{HB}-\mathrm{co}-3 \mathrm{HV})$ pellets was $38 \%$ and $13 \%$, respectively, but these differences are unreliable (Fig. 5).

These results cannot provide a basis for the conclusion that the processes of degradation of the two PHA types in the seawater are different or that the copolymer degrades at a higher rate than the $\mathrm{P}(3 \mathrm{HB})$ homopolymer. Compacted pellets have a smaller surface area and, hence, a smaller polymer/ water interface area than polymer films, and it may take a longer time for microorganisms to get attached to the surface and a longer time for the microorganisms to get adapted to the PHA as the substrate that has been subjected to compacting. Differences that we recorded in biodegradation patterns of PHA specimens of different shapes, prepared using different techniques, could, in our opinion, be accounted for by different structures and surface areas of specimens, which must have influenced the adhesion of microorganisms and their enzymatic activity.

Thus, it seemed reasonable to answer the question what processes occurred in the degrading polymer. Specimens were examined using X-ray structure analysis to determine whether disintegration of the polymer matrix 


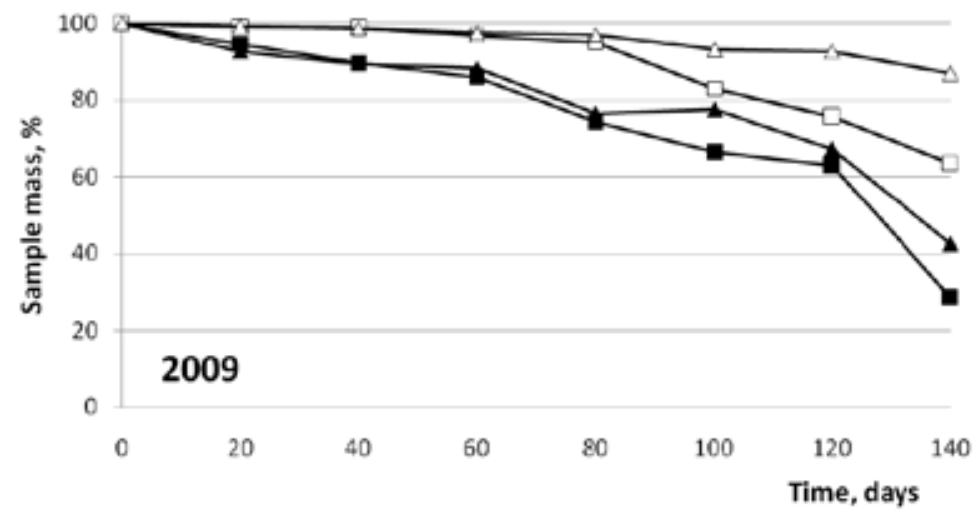

Film, PHB $\quad \leftarrow$ Film, PHBV $\quad$-Pellet, PHB $\_$-Pellet, PHBV

Fig. 5. Dynamics of the mass of polymer specimens in South China Sea

changed the ratio of the ordered phase to the disordered one, i.e. the degree of crystallinity of the polymer. Depolymerizing enzymes are assumed to preferentially degrade the amorphous (disordered) part of a polymer rather than its crystalline region (Abe et al., 1995).

Analysis of X-ray spectra of PHA specimens after 160 days of marine exposure did not reveal any change in their crystallinity. Thus, no changes were found in the proportions of the amorphous phase and the crystalline one in PHAs of both types as they degraded, suggesting a conclusion that in the marine environment studied, the amorphous phase of the PHA and the crystalline one were equally degraded, and, hence, the integrated indicator for the state of the polymer structure (crystallinity) remained unchanged.

Properties of the polymer are determined to a large extent by its molar mass, Mw (weight average molecular weight) in particular. Changes in molecular weight of PHA specimens after marine exposure were analyzed using gel permeating chromatography. Molecular weight of the specimens of all types was found to decrease during degradation; a decrease in $\mathrm{Mw}$ was recorded for films and pellets, prepared from both the $\mathrm{P}(3 \mathrm{HB})$ homopolymer and the $\mathrm{P}(3 \mathrm{HB}-$ co-3HV) copolymer. The most dramatic, $57 \%$, decrease in this parameter was obtained for copolymer pellets; in the other variants the decrease ranged between 16 and $26 \%$.

Polydispersity increased in specimens of all types, suggesting that the number of fragments having different degrees of polymerization was growing. Thus, during the course of PHA biodegradation in the marine environment, as the mass of the specimens was reduced, their Mw decreased too, which is in agreement with the data reported by other authors (Mergaert, Swings, 1996; Kim, Rhee, 2003). Degradation and mass loss of the specimens altered morphology of their surface, particularly that of films, whose degradation was more pronounced.

Microbiological investigations showed that in the seawater of the South China Sea, the total number of heterotrophic bacteria on the Y-K medium was $1.6 \times 10^{3} \mathrm{CFU}$ per $\mathrm{ml}$ and the number of microscopic fungi $1 \times 10^{2} \mathrm{CFU}$ per ml. Similar data were reported by other authors, who had been conducting microbiological investigations in the Sea of Japan and in coastal waters of Vietnam (Beleneva, Zhukova, 2009; Beleneva et al., 2007). 
Polymer specimens incubated in seawater for 160 days became covered with microbial biofilms. A total of 58 heterotrophic bacteria were isolated in pure cultures. Biofilm-forming microorganisms were represented by diverse morphological types.

Gram-negative rods prevailed, amounting to between $60 \%$ and $65 \%$ on different specimens. Isolated bacteria were representatives of the genera Pseudomonas, Pseudoalteromonas, Corynebacterium, Staphylococcus, Planococcus, Micrococcus, Arthrobacter, Cellulomonas, Enterobacter, Bacillus, and Gracilibacillus. Microscopic fungi were represented by Aspergillus, Penicillium, Trichoderma, Verticillium, Mucor, and Malbranchea.

PHA-degrading microorganisms were isolated by inoculating biofilm samples onto mineral agar that contained finely powdered PHA as sole carbon and energy source. Most of the isolated bacteria were unable to degrade the polymer. The occurrence of clear zones on the polymer-containing diagnostic medium (depolymerase activity) was recorded for six isolates of biofilm bacteria.

Based on similarities of morphological types, three strains capable of polymer biodegradation were selected from these isolates. These strains were subsequently identified based on the combination of morphological, cultural, and biochemical properties and determination of nucleotide sequences of the 16S rRNA gene.

Taxonomic and phylogenetic positions of the strains with PHA depolymerase activity were defined by determining nucleotide sequences of the 16S rRNA gene corresponding to position 8-1510 of E. coli nucleotides.

Having compared nucleotide sequences of the 16S rRNA gene segment of the isolated PHA degrading bacterial strains with the sequences in the GenBank, we revealed high homology with the sequences of the following cultured strains. The highest homology to IBP-V001 was exhibited by Enterobacter sp. BSRA2 and Enterobacter cloacae subsp. dissolvens isolated from marine sediment (99.5\%); to IBP-V002 - by two strains of Bacillus sp. -64 and CNJ905 PL04 (99.7-97.8 \%); to IBP-V003 - by Gracilibacillus sp. strains DstIV-1 and DstIII-1 (98.2 \%) (Table 1, Fig. 6). The proposed lowest levels of homology in the 16S rRNA nucleotide sequences are $97.5 \%$ and $95 \%$ for identification of bacterial species and genera, respectively (Stackebrandt, Goebel, 1994; Ludwig et al., 1998); thus, we identified the isolated PHA-degrading strains as Enterobacter cloacae IBP-V001, Bacillus sp. IBP-V002 and Gracilibacillus sp. IBP-V003. PHA-depolymerase activity of representatives of Bacillus megaterium was reported in the literature, and genes of intercellular PHB-depolymerase phaZ were
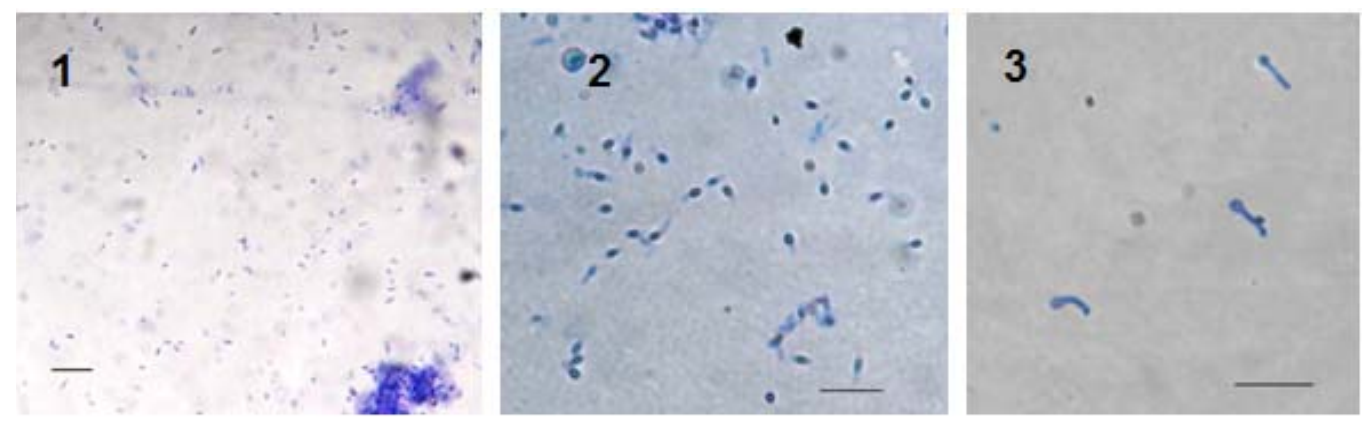

Fig. 6. PHA-degrading bacteria isolated from the South China Sea: 1 - Enterobacter cloacae, 2 - Bacillus sp., 3 - Gracilibacillus sp. Scale $10 \mu \mathrm{m}$ 
cloned and characterized for two strains of this taxon (ATCC 11561 and N-18-25-9) (Takaku et al., 2006; Chen et al., 2009). There are no data on PHA-depolymerase activity in representatives of the genera Gracilibacillus and Enterobacter in the available literature.

Similar investigations were performed in Lake Shira - a medicinal brackish lake. It was studied for years as a model of a rather simple ecosystem, and various data regarding this aquatic environment were obtained (Degermendzhy et al., 2010). Our study was the first to investigate PHA degradation in Lake Shira. Lake Shira is a brackish-water thermally stratified water body with a hydrogen sulfide hypolimnion zone. It is famous for its therapeutic muds and water. The mineral content of the water varies from 17.3 to $30 \mathrm{~g} / \mathrm{L}$ depending on the depth. The water is alkaline, with $\mathrm{pH}$ 8.9-9.2. The temperature of the water varies widely, with an amplitude of $24.6^{\circ} \mathrm{C}$, depending on the depth. The thermocline is situated at a depth of 6-8 m; the water temperature in the hypolimnion does not rise higher than $4^{\circ} \mathrm{C}$.

As the water salinity is high, the water freezes at temperatures below $0^{\circ} \mathrm{C}$. The water is covered with ice until mid May. Lake Shira is a unique aquatic environment because it exhibits a combinationofimportantphysicochemicalfactors: moderate mineral content and predominance of sulfate ions. The lake is stratified with respect to temperature, oxygen, and chemical parameters. The anaerobic zone, close to the lake bottom, contains great amounts of sulfides, phosphates, and ammonium. Other chemical elements are nonuniformly distributed over the lake area. Chemical stratification remains stable throughout the summer-autumn season, and Lake Shira can be classified as a meromictic water body.

Based on the vertical profiles of the temperature, dissolved oxygen, and redox potential, the Lake Shira water column can be divided into epilimnion, thermocline, oxygenic hypolimnion, and anoxygenic hypolymnion. The epilimnion (with the temperature decreasing by less than $1^{\circ} \mathrm{C}$ per $\mathrm{m}$ ) becomes deeper during summer, due to the heating of the water surface. The lower boundary of the epilimnion is shifted down from a June depth of $3 \mathrm{~m}$ to a depth of below 13-14 $\mathrm{m}$ by the end of summer.

The diversity of species in the lake ecosystem is poor, and there are rather few trophic levels. The lake is fish-free. The trophic chain includes bacteria, algae, zooplankton, and benthos (Degermendzhy, Gulati, 2002). Bacterioplankton - the major component of planktonic microbial community of the lake - comprise 65.3 to $75.7 \%$ of the total microbial biomass. The highest concentration of heterotrophic bacteria has been recorded in the lake monimolimnion.

The strategy of the experiment was based on these data and the fact that the lake is stratified with respect to temperature and chemical composition. As field work could only be performed when the lake was ice-free, the experiment on PHA degradation was started on June 13, 2007. Two PHA types were used: poly(3-hydroxybutyrate) $(\mathrm{P}(3 \mathrm{HB}))$ and poly(3-hydroxybutyrate-co-3hydroxyvalerate) (P(3HB-co-3HV)) (10 mol. \% 3HV).

PHA film discs were submerged to different depths $(3,9,13$, and $20 \mathrm{~m})$ in the central part of the lake, $1.5 \mathrm{~km}$ away from the shore. These depths correspond to the lake stratification layers with respect to temperature, oxygen, and some chemical parameters such as hydrogen sulfide and other sulfides.

During the summer season of 2007, hydrochemical parameters of Lake Shira changed as follows: the widest variations were recorded for the water temperature in the epilimnion. At the beginning of the experiment the water temperature at a depth of $3 \mathrm{~m}$ was $13^{\circ} \mathrm{C}$, reaching its maximum $\left(23-24^{\circ} \mathrm{C}\right)$ in mid July, and decreasing to the initial 
values in autumn. At a depth of $9 \mathrm{~m}$, temperature variations were less significant: $13-15^{\circ} \mathrm{C}$. In the chemocline and monimolimnion, temperature changes were even less significant: the average water temperatures were $5.0-6.0^{\circ} \mathrm{C}$ and $1.5-2.0^{\circ} \mathrm{C}$, respectively. Water salinity and dissolved oxygen concentration in each layer remained unchanged throughout the field season. Water $\mathrm{pH}$ dropped slightly in the upper water layers (from 8.9 to 8.5 ) and grew somewhat in the chemocline (from 8.85 to 9.0 ) and in the near-bottom layers (from 8.7 to 9.45).

Almost in all cases, degradation started after a lag phase (20-40 d), during which no statistically significant mass loss was recorded. Bacterioplankton may need a certain time period to adhere to the polymer film, adapt to the polymer as substrate for cell growth, and synthesize delopymerizing enzymes, which induce polymer degradation into monomers, followed by utilization of PHA degradation products by microbial cells. Another possible reason for the occurrence of the lag phase may be that depolymerizing enzymes first degraded the amorphous, more readily accessible, part of the polymer and cleaved the polymer chain, and then, when microorganisms began to utilize degradation products, the PHA molecular weight decreased and mass losses became noticeable.

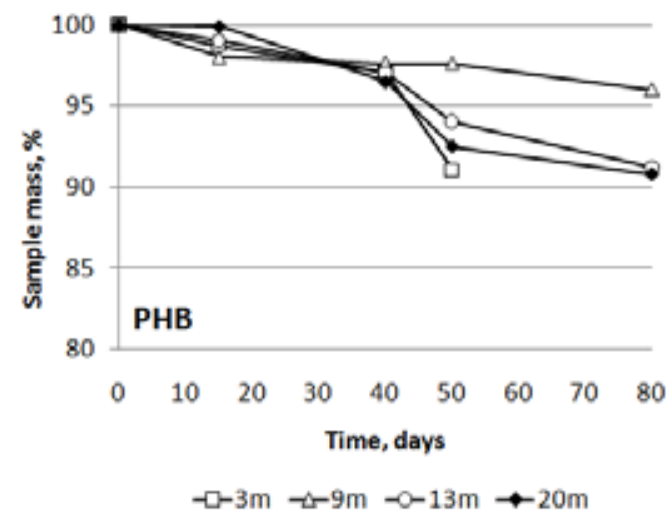

Mass loss of PHAs was recorded as late as early August, although the water temperature in the warmest layers of Lake Shira began to decrease. The most significant mass loss was recorded at a depth of $3 \mathrm{~m}$. After 50 days of incubation, the $\mathrm{P}(3 \mathrm{HB})$ mass decreased by $9.0 \%$, and the mass loss of $\mathrm{P}(3 \mathrm{HB}-\mathrm{co}-3 \mathrm{HV})$ films was even more considerable $-15.8 \%$. During this period of time (days 40-50) the average degradation rates of $\mathrm{P}(3 \mathrm{HB})$ and $\mathrm{P}(3 \mathrm{HB}-\mathrm{co}-3 \mathrm{HV})$ were 0.38 and $0.67 \mathrm{mg} / \mathrm{d}$, respectively. Unfortunately, later we lost these PHA films - they were carried away by the current flow. At depths of 13 $\mathrm{m}$ and $20 \mathrm{~m}$, the mass of PHA films decreased too, but to a lesser extent. In the chemocline and monimolimnion, the mass losses of $\mathrm{P}(3 \mathrm{HB})$ and $\mathrm{P}(3 \mathrm{HB}-\mathrm{co}-3 \mathrm{HV})$ films were $8.8 \%$ and $9.2 \%$ and $13.3 \%$ and $16.2 \%$ of the initial masses, respectively, at the end of the field season. No significant mass loss of the films was recorded at a depth of 9 m. (Fig. 7).

Analysis of measurements of weight average $(\mathrm{Mw})$ and number average $(\mathrm{Mn})$ molecular weights of the polymers and their polydispersity (PD) values showed that the $\mathrm{Mw}$ and $\mathrm{Mn}$ of all specimens decreased. The most significant decrease was recorded in the specimens placed at a depth of $3 \mathrm{~m}$ and below the chemocline, and these results were consistent with the data on

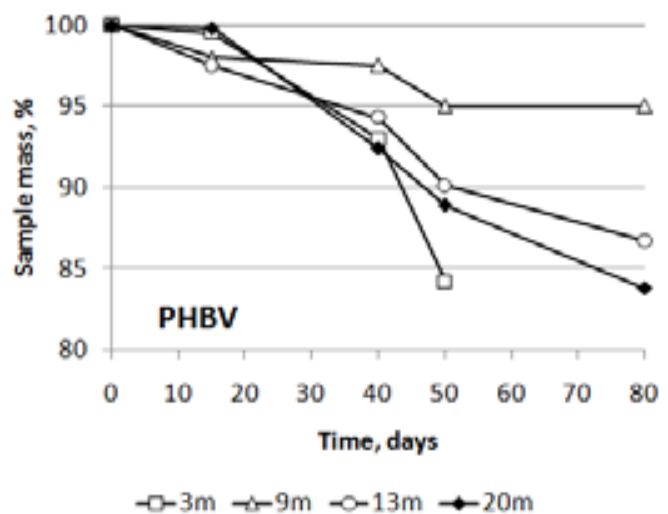

Fig. 7. Dynamics of the mass of polymer specimens in Lake Shira 
the mass loss of the specimens. The decrease in the molecular weight of the copolymer was greater, and this result also agrees well with the greater mass loss of the $\mathrm{P}(3 \mathrm{HB}-\mathrm{co}-3 \mathrm{HV})$ films. PHA polydispersity increased, suggesting that polymer chains were cleaved and the number of fragments with different degrees of polymerization was growing.

Thus, PHA degradation occurred at different depths of Lake Shira. The most significant degradation was recorded in the epilimnion, at a depth of $3 \mathrm{~m}$, i.e. in the warmest lake layer with the best air supply, and in the oxygenic-anoxygenic layers, at depths of 13 and $20 \mathrm{~m}$, in the absence of oxygen but in the presence of hydrogen sulfide, at low temperatures.

The fact that PHA specimens were degraded in the anoxygenic monimolimnion at a depth of $20 \mathrm{~m}$ can be accounted for by the activity of anaerobic heterotrophic and, probably, chemosynthesizing microorganisms, whose concentrations at this depth are higher than in other water layers of the lake.

This study proved that PHAs can be degraded at different depths of the brackish lake and that the less crystalline copolymer of 3-hydroxybutyrate and 3-hydroxyvalerate is degraded with a higher rate than the homogenous poly(3-hydroxybutyrate). The highest degradation rates of $\mathrm{P}(3 \mathrm{HB})$ and $\mathrm{P}(3 \mathrm{HB}$ -
co-3HV) (0.4 and $0.7 \mathrm{mg} / \mathrm{d}$, respectively) were recorded in the oxygenic epilimnion. In the anoxygenic, low-temperature chemocline and monimolimnion, PHAs of both types were degraded at slower rates (0.05-0.25 and 0.1-0.3 $\mathrm{mg} / \mathrm{d}$ for $\mathrm{P}(3 \mathrm{HB})$ and $\mathrm{P}(3 \mathrm{HB}-\mathrm{co}-3 \mathrm{HV})$, respectively).

\section{Conclusion}

Studies of PHA degradation in different natural freshwater and saltwater environments showed that PHA biodegradation is influenced by the chemical structure of the polymer, its geometry and the technique used to process it; climate and weather, the type of the natural ecosystem and its microbial component in particular, as the factor determining the mechanism of PHA biodegradation: preferential attack of the amorphous regions of the polymer or equal degradation of both crystalline and amorphous phases. PHA degrading microorganisms that dominate microbial populations in some soil and aquatic ecosystems have been isolated and identified.

\section{Ackonowledgements}

The study was supported by the State budget allocated to the fundamental research at the Russian Academy of Sciences (project № 01201351505).

\section{References}

1. Abe H., Doi Y.(1996) Enzymatic and environmental degradation of racemic poly(3-hydroxybutyric acid)s with different stereoregularities. Macromolecules 29: 8683-8688.

2. Abe H., Doi Y. (1999) Structure effects on enzymatic degradabilities for poly[(R)-3hydroxybutyric acid] and copolymers. International Journal of Biological Macromolecules 25: 185-192.

3. Abe H., Matsubara I., Doi Y. (1995) Physical properties and enzymatic degradability of polymer blends of bacterial poly[(R)-3-hydroxybutyrate $]$ and poly[(R,S)-3-hydroxybutyrate] stereoisomers. Macromolecules 28: 844-853.

4. Abou-Zeid D.M., Muller R.J., Deckwer W.D. (2001) Degradation of natural and synthetic polyesters under anaerobic conditions. Journal of Biotechnology 86: 113-126. 
5. Abou-Zeid D.M., Muller R.J., Deckwer W.D. (2004) Biodegradation of alifatic homopolyesters and aliphatic-aromatic copolyesters by anaerobic microorganisms. Biomacromolecules 5: 16871697.

6. Beleneva I.A., Zhukova N.V. (2009) Seasonal dynamics of cell numbers and biodiversity of marine heterotrophic bacteria inhabiting invertebrates and water ecosystems of the Peter the Great Bay, Sea of Japan. Microbiology 78: 369-375.

7. Beleneva I.A., Zhukova N.V., Le Lan H., Nguyen Tran D.H. (2007) Taxonomic composition of bacteria associated with cultivated mollusks Crassostrea lugubris and Perna viridis and with the water of the Gulf of Nha Trang Lagoon, Vietnam. Microbiology 76: 220-228.

8. Brandl H., Puchner P. (1992) Biodegradation of plastic bottles made from 'Biopol' in an aquatic ecosystem under in situ conditions. Biodegradation 2: 237-243.

9. Briese B.H., Jendrossek D., Schlegel H.G. (1994) Degradation of poly(3-hydroxybutyrate-co-3hydroxyvalerate) by aerobic sewage sludge. FEMS Microbiology Letters 117: 107-112.

10. Chen H.J., Pan S.C., Shaw G.C. (2009) Identification and characterization of a novel intracellular poly(3-hydroxybutyrate) depolymerase from Bacillus megaterium. Applied and Environmental Microbiology 75: 5290-5299.

11. Chowdhury A.A. (1963) Poly-ß-hydroxybuttersäure abbauende Bakterien und Exoenzym. Archives of Microbiology 47: 167-200.

12. Degermendzhy A.G., Gulati R.D. (2002) Understanding the mechanisms of blooming of phytoplankton in Lake Shira, a saline lake in Siberia (the Republic of Khakasia). Aquatic Ecology 36: $331-340$.

13. Degermendzhy A.G., Zadereev E.S., Rogozin D.Y., Prokopkin I.G., Barkhatov Y.V., Tolomeev A.P., Khromechek E.B, Janse J.H., Mooij W.M., Gulati R.D. (2010) Vertical stratification of physical, chemical and biological components in two saline lakes Shira and Shunet (South Siberia, Russia). Aquatic Ecology 44: 619-632.

14. Delafield F.P., Doudoroff M., Palleroni N.J., Lusty C.J., Contopoulos R. (1965) Decomposition of poly- $\beta$-hydroxybutyrate by pseudomonas. Journal of Bacteriology 90: 1455-1466.

15. Doi Y., Kanesawa Y., Tanahashi N., Kumagai Y. (1989) Biodegradation of microbial poly(hydroxyalkanoates). Macromolecular Chemistry Rapid Communications 10: 227-230.

16. Doi Y., Kanesawa Y., Kawaguchi Y., Kunioka M. (1992) Hydrolytic degradation of microbial polyesters in the marine environment. Polymer Degradation and Stability 36: 173-177.

17. Doi Y., Segawa A., Kawaguchi Y., Kunioka M. (1990) Cyclic nature of poly(3-hydroxyalkanoate) metabolism in Alcaligenes eutrophus. FEMS Microbiology Letters 67: 165-170.

18. Freier T., Kunze C., Nischan C., Kramer S., Sternberg K., Saß M., Hopt U.T., Schmitz K.P. (2002) In vitro and in vivo degradation studies for development of a biodegradable patch based on poly(3hydroxybutyrate). Biomaterials 23: 2649-2657.

19. Hocking P.J., Marchessault R.H., Timmins M.R., Lenz R.W., Fuller R.C. (1996) Enzymatic degradation of single crystals of bacterial and synthetic poly( $\beta$-hydroxybutyrate). Macromolecules 29: $2472-2478$.

20. Imam S.H., Gordon S.H., Schogren R.L., Tosteson T.R., Govind N.S., Greene R.V. (1999) Degradation of starch-poly(beta-hydroxybutyrate-co-beta-hydroxyvalerate) bioplastic in tropical coastal waters. Applied and Environmental Microbiology 65: 431-437. 
21. Janssen P.H., Schink B. (1993) Pathway of anaerobic poly- $\beta$-hydroxybutyrate degradation by Ilyobacter delafieldii. Biodegradation 4: 179-185.

22. Jendrossek D., Handrick R. (2002) Microbial degradation of polyhydroxyalkanoates. Annual Review of Microbiology 56: 403-432.

23. Kasuya K., Inoue Y., Tanaka T., Akehata T., Iwata T., Fukui T., Doi Y. (1997) Biochemical and molecular characterization of the polyhydroxybutyrate depolymerase of Comamonas acidovorans YM1609, isolated from freshwater. Applied and Environmental Microbiology 63: 4844-4852.

24. Kim D.Y., Rhee Y.H. (2003) Biodergadation of microbial and synthetic polyesters by fungi. Applied Microbiology and Biothechnology 61: 300-308.

25. Knoll M., Hamm T.M., Wagner F., Martinez V., Pleiss J. (2009) The PHA Depolymerase Engineering Database: a systematic analysis tool for the diverse family of polyhydroxyalkanoate (PHA) depolymerases. BMC Bioinformatics 10: 89-97.

26. Koyama N., Doi Y. (1997) Effects of solid-state structures on the enzymatic degradability of bacterial PHA. Macromolecules 30: 826-832.

27. Kumagai Y., Kanesawa Y., Doi Y. (1992) Enzymatic degradation of microbial poly(3hydroxybutyrate) films. Macromolecular Chemistry 193: 53-57.

28. Kusaka S., Iwata T., Doi Y. (1999) Properties and biodegradability of ultra-high-molecular-weight poly[(R)-3-hydroxybutyrate] produced by recombinant Escherichia coli. International Journal of Biological Macromolecules 25: 87-94.

29. Lee K.M., Gimore D.F., Huss M.J. (2005) Fungal degradation of the bioplastic PHB (poly-3hydroxybutyric acid). Journal of Polymers and the Environment 13: 213-219.

30. Lootz D., Holbe J., Behrend D., Schmitz K.P. (1998) Comparative studies of the degradation kinetics and effect on mechanical properties of polylactide and polyhydroxybutyric acid in vitro. Biomedizinische Technik 43: 428-429 (in German).

31. Ludwig W., Strunk O., Klugbauer S., Klugbauer N., Weizenegger M., Neumaier J., Bachleitner M., Schleifer K.H. (1998) Bacterial phylogeny based on comparative sequence analysis. Electrophoresis 19: 554-568.

32. Martin D.P., Skraly F.A., Williams S.F., inventors; Metabolix Inc., assignee. (2004, Dec 7) Polyhydroxyalkanoate compositions having controlled degradation rates. United States patent US 6828357.

33. Mergaert J., Anderson C., Wouters A., Swings J. (1994) Microbial degradation of poly(3hydroxybutyrate) and poly(3-hydroxybutyrate-co-3-hydroxyvalerate) in compost. Journal of Environmental Polymer Degradation 2: 177-183.

34. Mergaert J., Glorieux G., Hauben L., Storms V., Mau M., Swings J. (1996) Biodegradation of poly(3hydroxyalkanoates) in anaerobic sludge and characterization of a poly(3-hydroxyalkanoates) degrading anaerobic bacterium. Systematic and Applied Microbiology 19: 407-413.

35. Mergaert J., Swings J. (1996) Biodiversity of microorganisms that degrade bacterial and synthetic polyesters. Journal of Industrial Microbiology 17: 463-469.

36. Mergaert J., Webb A., Anderson C., Wouters A., Swings J. (1993) Microbial degradation of poly(3-hydroxybutyrate) and poly(3-hydroxybutyrate-co-3-hydroxyvalerate) in soils. Applied and Environmental Microbiology 59: 3233-3238. 
37. Mergaert J., Wouters A., Swings J., Anderson C. (1995) In situ biodegradation of poly(3hydroxybutyrate) and poly(3-hydroxybutyrate-co-3-hydroxyvalerate) in natural waters. Canadian Journal of Microbiology 41 Suppl 1: 154-159.

38. Miller N.D., Williams D.F. (1987) On the biodegradation of poly- $\beta$-hydroxybutyrate (PHB) homopolymer and poly- $\beta$-hydroxybutyrate-hydroxyvalerate copolymers. Biomaterials 8: 129-137.

39. Morse M.C., Liao Q., Criddle C.S., Frank C.W. (2011) Anaerobic biodegradation of the microbial copolymer poly(3-hydroxybutyrate-co-3-hydroxyhexanoate): Effects of comonomer content, processing history, and semi-crystalline morphology. Polymer 52: 547-556.

40. Nishida H., Tokiwa Y. (1993) Effects of high-order structure of poly(3-hydroxybutyrate) on its biodegradation. II. Effects of crystal structure on microbial degradation. Journal of Environmental Polymer Degradation 1: 65-80.

41. Nobes G.A.R., Marchessault R.H., Briese B.H., Jendrossek D. (1998) Microscopic visualization of the enzymatic degradation of poly(3HB-co-3HV) and poly(3HV) single crystals by PHA depolymerases from Pseudomonas lemoignei. Journal of Environmental Polymer Degradation 6: 99-107.

42. Oda Y., AsariH.,Urakami T., Tonomura K.(1995)Microbialdegradation of poly(3-hydroxybutyrate) and polycaprolactone by filamentous fungi. Journal of Fermentation and Bioengineering 80: 265269.

43. Prudnikova S.V., Boyandin A.N., Karpov V.A., Lê Thị Mỹ Hiệp, Filichev N.L., Gitelson I.I. (2015) Microbial degradation of polyhydroxyalkanoates in fresh tropical water. Journal of Siberian Federal University. Biology 8 (2): 187-198.

44. Renard E., Walls M., Guérin P., Langlois V. (2004) Hydrolytic degradation of blends of polyhydroxyalkanoates and functionalized polyhydroxyalkanoates. Polymer Degradation and Stability 85: 779-787.

45. Rutkowska M., Krasowska K., Heimowska A. (2008) Environmental degradation of blends of atactic poly[(R,S)-3-hydroxybutyrate] with natural PHBV in Baltic sea water and compost with activated sludge. Journal of Polymers and the Environment 16: 183-191.

46. Salim Y.S., Sharon A., Vigneswari S., Ibrahim M.M., Amirul A.A. (2012) Environmental degradation of microbial polyhydroxyalkanoates and oil palm-based composites. Applied Biochemistry and Biotechnology 167: 314-326.

47. Schöber U., Thiel C., Jendrossek D. (2000) Poly(3-hydroxyvalerate) depolymerase of Pseudomonas lemoignei. Applied and Environmental Microbiology 66: 1385-1392.

48. Shah A., Hasan F., Hameed A., Ahmed S. (2007) Isolation and characterization of poly(3hydroxybutyrate-co-3-hydroxyvalerate) degrading bacteriaand purification of PHBV depolymerase from newly isolated Bacillus sp. AF3. International Biodeterioration and Biodegradation 60: 109115.

49. Shangguan Y.Y., Wang Y.W., Wu Q., Chen G.Q. (2006) The mechanical properties and in vitro biodegradation and biocompatibility of UV-treated poly(3-hydroxybutyrate-co-3hydroxyhexanoate). Biomaterials 27: 2349-2357.

50. Sridewi N., Bhubalan K., Sudesh K. (2006) Degradation of commercially important polyhydroxyalkanoates in tropical mangrove ecosystem. Polymer Degradation and Stability 91: 2931-2940. 
51. Stackebrandt E., Goebel B.M. (1994) Taxonomic note: a place for DNA-DNA reassociation and $16 \mathrm{~S}$ rRNA sequence analysis in the present species definition in Bacteriology. International Journal of Systematic Bacteriology 44: 846-849.

52. Suyama T., Tokiwa Y., Ouichanpagdee P., Kanagawa T., Kamagata Y.(1998) Phylogenetic affiliation of soil bacteria that degrade aliphatic polyesters available commercially as biodegradable plastics. Applied and Environmental Microbiology 64: 5008-5011.

53. Takaku H., Kimoto A., Kodaira S., Nashimoto M., Takagi M. (2006) Isolation of a Grampositive poly(3-hydroxybutyrate) (PHB)-degrading bacterium from compost, and cloning and characterization of a gene encoding PHB depolymerase of Bacillus megaterium N-18-25-9. FEMS Microbiology Letters 264: 152-159.

54. Takeda M., Koizumi J., Yabe K., Adachi K. (1998) Thermostable poly(3-hydroxybutyrate) depolymerase of a thermophilic strain of Leptothrix sp. isolated from a hot spring. Journal of Fermentation and Bioengineering 85: 375-380.

55. Tomasi G., Scandola M., Briese B.H., Jendrossek D. (1996) Enzymatic degradation of bacterial poly(3-hydroxybutyrate) by a depolymerase from Pseudomonas lemoigeni. Macromolecules 29: 507-513.

56. Urmeneta J., Mas-Castella J., Guerrero R. (1995) Biodegradation of poly-(beta)-hydroxyalkanoates in a lake sediment sample increases bacterial sulfate reduction. Applied and Environmental Microbiology 61: 2046-2048.

57. Volova T.G., Boyandin A.N., Vasiliev A.D., Karpov V.A., Prudnikova S.V., Mishukova O.V., Boyarskikh U.A., Filipenko M.L., Rudnev V.P., Bùi Bá Xuân, Vũ Việt Dũng, Gitelson I.I. (2010) Biodegradation of polyhydroxyalkanoates (PHAs) in tropical coastal waters and identification of PHA-degrading bacteria. Polymer Degradation and Stability 95: 2350-2359.

58. Volova T.G.,GladyshevM.I.,TrusovaM.Y.,ZhilaN.O.(2006)Degradation of polyhydroxyalkanoates and the composition of microbial destructors under natural conditions. Microbiology 75: 593598.

59. Volova T.G.,GladyshevM.I., TrusovaM.Y.,ZhilaN.O.(2007)Degradation of polyhydroxyalkanoates in eutrophic reservoir. Polymer Degradation and Stability 92: 580-586.

60. Wen X., Lu X. (2012) Microbial degradation of poly (3-hydroxybutyrate-co-4-hydroxybutyrate) in soil. Journal of Polymers and the Environment 20: 381-387.

61. Yamane H., Terao K., Hiki S., Kawahara Y., Kimura Y., Saito T. (2001) Enzymatic degradation of bacterial homo-poly(3-hydroxybutyrate) melt spun fibers. Polymer 42: 7873-7878.

62. Yasin M., Tighe B.J. (1992a) Polymers for medical devices: VII. Hydoxybutyrate-hydroxyvalerate copolymers: physical and degradative properties of blends with polycaprolacton. Clinical Materials 10: 21-28.

63. Yasin M., Tighe B.J. (1992b) Polymers for medical devices: VIII. Hydoxybutyrate-hydroxyvalerate copolymers: physical and degradative properties of blends with polycaprolacton. Biomaterials 13: 9-16. 